\title{
Do all roads lead to Uman? The Hasidic pilgrimage during the pandemic times
}

\author{
Alla Marchenko \\ Polish Academy of Sciences
}

\begin{abstract}
In this text, I analyze official public narratives in Ukraine in 2020 connected to the Hasidic pilgrimage to Uman, the best known and most popular destination of its kind in Europe. The pandemic year 2020 brought restrictions to mass gatherings, including the pilgrimages, for the first time since the collapse of the Soviet Union. I have differentiated two competing discourses connected to the pilgrimage - "pilgrimage as a source of danger" and "pilgrimage as a proxy for Ukraine's good reputation", both of which unveiled the problem of representation. The case of the Hasidic pilgrimage to Uman during the pandemic times could serve as a model for building a common official position of various levels of authority on a nuanced topic.
\end{abstract}

\section{Keywords}

Uman, Hasidic pilgrimages, pandemic, official discourses, media discourses

\section{Contact Address}

Graduate School for Social Research, Institute of Philosophy and Sociology, Polish Academy of Sciences, 72 Nowy Świat Str., Warsaw, Poland, 00-330

amarchen@gssr.edu.pl

\section{Introduction}

Pilgrimages as a manifestation of religious beliefs attached to journeys to certain places in the world still occur despite the modern world's rationalization and disenchantment, as Max Weber observed. ${ }^{1}$ Zygmunt Bauman argued that the contemporary world leaves less and less space for pilgrims with their search for deep meaning, and it replaces them with

${ }^{1}$ Weber, Sociology of Religion, 270. 
tourists who search for superficial impressions. ${ }^{2}$ The number of pilgrims in the world is, however, growing. Despite many definitions and contexts of pilgrimage, the presence of a shrine, a sacred object is what differentiates pilgrimage from other forms of mass movement in space. Daniele Hervieu-Leger offered to widen the field of 'religious' beyond 'belonging to religion' to the search of meaning, ${ }^{3}$ which can be well suited for an understanding of pilgrimages in the contemporary world.

In this article, I analyze official discourses around the case of the Hasidic pilgrimage to Uman in 2020, aiming to investigate questions such as: Why did this case move from the local political decisions to international debates among the highest-rank officials? Which political messages relevant for this case can be important in a wider context beyond 2020?

I start with the peculiarity of 2020 and an outline of the pilgrimage case in Uman. Later on, I move to methodology and main research results, discussing sociocultural context, text level, and discursive practices in the analysis. In the conclusions, I reflect upon the problems and perspectives unveiled in the official messages relevant to the case.

\section{The year 2020}

The year 2020 marked the beginning and development of the pandemic caused by the COVID-19 coronavirus. The virus originated in China in late 2019, quickly spread across the continents and provided an unprecedented reason for closing national borders and limiting the movement of people. Traveling became unpredictable and challenging after March 2020 and remains so at the time of this writing. The word 'lockdown', which means "the imposition of stringent restrictions on travel, social interaction, and access to public spaces" in Collins dictionary, has become the word of the year. ${ }^{4}$ According to AFP data in early April, half of humanity experienced lockdown due to strict state restrictions to social activities. ${ }^{5}$

Although countries reacted differently, in general, the first wave of restrictions began in spring 2020, and the second one in the fall. There were also exceptions, for instance, three lockdowns in Israel in 2020 or postponing the second lockdown in Ukraine until January 2021.

The world's well-known pilgrimages faced major challenges. For instance, Islamic Hajj was allowed for only 1,000 people instead of 2 mln pilgrims. ${ }^{6}$ The world's largest Catholic pilgrimage for the Virgin of Guadalupe in Mexico was canceled by the Church. ${ }^{7}$ Other pilgrimages underwent restrictions depending on the time and the country of pilgrimage,

\footnotetext{
${ }^{2}$ Bauman, "From Pilgrim to Tourist," 23.

${ }^{3}$ Hervieu-Leger, Religion as a Chain of Memory, 52.

${ }^{4}$ Porterfield, "Lockdown' Is 2020's Word Of The Year".

${ }^{5}$ Sandford. "Coronavirus: Half of Humanity Now on Lockdown...".

${ }^{6}$ Karadsheh and Qiblawi, “'Unprecedented' Hajj Begins...”.

7 "Catholic Church Cancels Guadalupe Pilgrimage over Pandemic".
} 
and the specificity of the pilgrimage. The largest Hasidic ${ }^{8}$ pilgrimage in the world, on Mount Meron in Israel, was banned by the Israeli government in May 2020. ${ }^{9}$ The Hasidic pilgrimage to Uman - the largest Hasidic pilgrimage in Europe ${ }^{10}-$ followed a path of negotiations and discussions.

\section{Specificity of the Uman pilgrimage}

The pilgrims who come to Uman represent various streams (Hasidic as well as others). The majority of these pilgrims are Breslov Hasidim ${ }^{11}$. They come to visit the burial place of Rebbe Nachman from Breslov (now Bratslav, Ukraine), according to his testament, during Rosh Hashanah time (New Year, according to the Jewish calendar) in the fall. Breslov Hasidism as a movement gained its popularity in recent years. The first pilgrimages after the death of Rebbe Nachman in 1810 had several dozen visitors, contemporary pilgrimages during Rosh Hashanah reached up to 30,000 people in the 2010s. Pilgrims come throughout the year, however, and several hundreds of Jews (mostly from Israel) live in Uman regularly. Some of them have become citizens of Ukraine. This makes the definition of a pilgrim and a local in Uman sometimes more blurry than in other places of the Hasidic pilgrimage. The specificity of the Uman pilgrimage is defined by several factors. First, it is connected with general Jewish aspects in local history and the peculiar Hasidic heritage, both of which were not only neglected but unmentionable in Soviet times. This is also one of the reasons for the high sensitivity of many potential pilgrims to any possible restrictions in current times. Second, Uman has a specific meaning for the core group of the pilgrimage - the Breslov Hasidim. According to their beliefs, the grave of their spiritual leader must be reached despite all obstacles, and obstacles only make the level of pilgrims' spirituality higher. Third, the most evident feature during the pandemic year, many of these pilgrims have their logic of rationality, oriented by faith and religion, not by science or medicine. The third aspect is connected by the general distance of the Hasidic groups from other groups in their home countries, including Israel. Fourth, many Hasidim from Israel (i.e., the majority of Uman Hasidic pilgrims) are mistrustful of or skeptical of the government of Israel. This is explained by historical reasons that go beyond the scope of this article. This factor explains the indifference of many potential pilgrims to the official policy of the Israeli government not to visit Ukraine in 2020. These four factors largely

8 The Hasidim are a number of groups within Judaism often labeled as 'Ultra-Orthodox' or 'Haredi'.

9 Staff, "No Lockdown, but Ministers Ban Bonfires, Close off Meron ahead of Lag B'Omer".

${ }_{10}$ The word 'Hasid' means 'pious', from Hebrew. The Hasidic movement appeared and developed in the eighteenth century as a side movement against Orthodox Judaism. Today, it represents a set of streams that are often labeled 'Ultra-Orthodox', or 'Haredi' for their level of religious devotion. Most scholars of Hasidism (Marcin Wodziński, David Białe, Moshe Rosman, etc.) agree that the Hasidic movement has developed in a powerful stream, which is not a side movement anymore (on this see Biale et al, 018).

11 "Hasidim" is a plural form of a noun 'Hasid", which originated in Hebrew and became accepted in academic literature in English. There are different ways of spelling of this group of the Hasidim: "Brarslav", "Breslav", "Breslev", etc. In this text, I use "Breslov" as a conventional form. 
explain why Hasidic pilgrimages to Uman have attracted so much media attention, especially, but not only, in 2020 .

The case of the Uman pilgrimage is generally known in Ukraine; it became one of the topics in the last season of the TV series "Servant of the People", where the actor Volodymyr Zelensky played the role of the President of Ukraine. There, Uman was shown as a separate 'kosher republic' on the new map of Ukraine as part of a series of specific humor. ${ }^{12}$ Volodymyr Zelensky became the first ethnically Jewish President of Ukraine in 2019, ${ }^{13}$ which enabled his perception in pilgrims' circles as 'Ours'. Interestingly, it was the President of Ukraine Volodymyr Zelensky who created a special committee focused on investigating cases of corruption in Uman connected with the construction of the long-announced largest synagogue in 2019. ${ }^{14}$ This explains the strong hopes of the Hasidim for Volodymyr Zelensky as the one who will allow them entry to Ukraine in 2020.

\section{Methodology}

In this text, I use the official documents of national bodies of power and their representatives, as well as local bodies of power (the mayor of Uman, local administration, etc.) and representatives of the Jewish community voicing the side of the pilgrimage. At the same time, I take into account interviews with officials representing opinions about the topic in the mass media. In the case of local authorities in Uman, I also use information from their official Facebook profiles. I rely on critical discourse analysis ${ }^{15}$ as the main tool for understanding the place of the pilgrimage in a wider political context among different groups of interest. It is worth noting that Facebook became one of the most convenient platforms for public discussions initiated by officials on the local level. In this regard, an important question raised by this research was the definition of an official document, i.e., when should a publicly-stated opinion be considered an official position? For instance, the Uman mayor at that time, Oleksandr Tsebrii, used his Facebook page for posting questions to Uman locals about the pilgrimage or for short videos where he articulated his negative attitude to the pilgrimage during the pandemic. ${ }^{16} \mathrm{His}$ political rival, a national deputy Anton Iatsenko used his Facebook page for scans of his official appeals about the ban on the pilgrimage during the pandemic to the Prime Minister of Ukraine, the Minister of Foreign Affairs of Ukraine, and the Minister of Health of Ukraine sealed and with signatures - as proof of his position. ${ }^{17}$ The president of the International Charity Foundation

\footnotetext{
12 "Vid Korolivstva Troieshchyna do Koshernoii respubliky..."

${ }^{13}$ Marchenko, "The Personal is Political...", 104-106.

14 "Zelens'ky stvoryv komisiiu..."

${ }^{15}$ Fairclough, "Critical Discourse Analysis as a Method in Social Scientific Research," 121-138.

${ }^{16}$ For instance, Oleksandr Tsebrii, "Shanovni umanchany! Potribno poradytys'."; Oleksandr Tsebrii, "Zvernennia do Prezydenta Ukrainy...”.

${ }^{17}$ Iatsenko, "Tradytsiyno shchoroku na sviatkuvannia Rosh Hashanah..."; Iatsenko, "U zviazku z pandemieiu..."; Iatsenko, "U ts'omu rotsi palomnyky-hasydy ne poiidut' do Umani...”.
} 
in Memory of Rabbi Nachman of Breslov Natan Nissim ben Nun posted the position of the Foundation on its official blank. ${ }^{18}$

For this research, I treated scans of documents linked with the official organization as official, and I treated the official web pages of politicians as their political platforms regardless of their writing style. I also took into consideration interviews with the officials distributed in the media as a source of official information (e.g., an interview of "the Uman media" with the local official Larysa Kachanova and her report on the epidemiological situation in Uman). ${ }^{19}$

Previous research shows ${ }^{20}$ that the mass media in pre-pandemic times was connected with four discourses - "pilgrimage as a challenge" and "pilgrimage as a source of inspiration" on the side of the pilgrims, as well as "pilgrimage as a disaster" and "pilgrimage as an unknown phenomenon" on the side of the locals. My tentative hypothesis is that the main discourse in political speeches about the pilgrimage during the pandemic would be connecting pilgrims to the potential source of infection and a danger to the locals.

\section{Research results}

According to the scheme of critical discourse analysis I employ, research results are divided into three parts: sociocultural context, text level and discourse level.

The sociocultural context shows the unprecedented and unpredictable situation of pandemic development, where every decision could be followed by a contrasting decision, and a decision on one level could be contested on a different level. The absence of a stable standpoint among groups of interest in the turbulent times led to more negative emotions among the local inhabitants of Uman both towards the authorities (for an inability to stop the pandemic) and the pilgrims (for their being dangerous as outsiders as well as for their disregard of pandemic guidelines by traveling).

On August 27, the Government of Ukraine announced the closure of the borders to all foreigners from August 28 until September 28 under the pretext of coronavirus infection spreading. The rapid character of this decision and the coincidence of the ban period with the Jewish High Holy Days (Rosh Hashanah on September 18-20 and Yom Kippur, or Atonement Day, on September 27-28) provoked, however, many discussions in the Ukrainian media that the dangers of the potentially numerous Hasidic pilgrimage to Uman during the pandemic had been the real reason for this decision. ${ }^{21}$ Unclear messages about the pilgrimage from various political sides led to uncertainty in understanding what was happening in Uman.

Political turmoil in Belarus, which began in late May 2020, intensified in August, and several neighboring countries (Lithuania, Poland) declared their readiness to provide shelter

\footnotetext{
${ }^{18}$ Natan Nissim Ben-Nun. "Na zhal', zmusheni konstatuvaty...”.

19 "Epidsytuacia w Umani pislia Rosh Hashanah".

${ }^{20}$ Marchenko, "Etic and emic approaches to the collective memory...”.

21 "Zaborona viizdu inozemtsiam - hto pidpadaie pid vykliuchennia...".
} 
to the Belarusian refugees by September 2020. This could serve as one of the explanations for the Ukrainian-Belarusian border conflict connected with about 1,500 Hasidim attempting to get to Uman due to their being certain they would be allowed to enter from the Belarusian side. The situation by the border led to several diplomatic letters with a strict position about no entry for the foreigners to Ukraine and no exclusion for the Hasidim. ${ }^{22}$ This situation also provoked a special appeal by Alexander Lukashenko, the (questionable) President of Belarus, to the Ukrainian central authorities about the possibility of letting the pilgrims go to their shrine in Ukraine (meaning: Uman) and coming back in direct transport that would be provided by Belarus. ${ }^{23}$ The agreement of the Ukrainian authorities with this step from Lukashenko might have been interpreted as an endorsement and lead to the turmoil in Uman with local inhabitants. At the same time, the mentioned Lukashenko's step towards the Hasidim could be treated as a preparatory attempt to violate the borders of neighbouring states - the latter was done by Belarusian advertisements for the migrants from various countries in the Arab world to have an efficient way to get to European Union and creating a Belarusian-Polish border turbulence in late 2021

The situation by the border created jokes and at least one unusual situation, namely an attempt by some Jewish pilgrims dressed in Ukrainian traditional clothes to sing the Ukrainian anthem and thank Volodymyr Zelensky, the President of Ukraine, for letting them into Ukraine. ${ }^{24}$ The International Charity Foundation in Memory of Rabbi Nachman of Breslov consequently published a statement that the video was a fake, noting the Cossack style of clothing. ${ }^{25}$ The result of the border stay conformed with the earlier announced law in Ukraine: the pilgrims were not let into Ukraine. Due to the implementation of border restrictions at the last minute, however, some pilgrims managed to reach Uman earlier. Some other pilgrims had Ukrainian documents that enabled the possibility of their arrival, and some Hasidim already lived in Ukraine. All in all, the Hasidic pilgrimage in Uman for Rosh Hashanah 5,781 (2020) consisted of about 2,000-2,500 pilgrims. ${ }^{26}$

The pilgrimage period coincided with the electoral competition on a municipal level. Oleksandr Tsebrii, the mayor at that time, started public debates on his Facebook page, posing the question as to whether Uman should be open to thousands of pilgrims from all over the world during the pandemic. ${ }^{27}$ His post received relatively significant attention (281 likes, 370 comments, 169 shares). A majority of the commentators declared their negative attitude to the pilgrimage during the pandemic, for instance: "We were sitting and praying at home during our Easter, we did not visit cemeteries on memorial days, so they

\footnotetext{
22 "Komentar MZS Ukrainy shchodo sytuacii na ukrains'ko-bilorus'komu derzhavnomu kordoni”;

"Komentar Ministerstva zakordonnyh sprav Ukrainy shchodo sytuacii na ukrains'ko-bilorus'komu derzhavnomu kordoni”.

23 “Lukashenko poruchil pravitel'stvu dogovorit'sa s Ukrainoy...”.

24 "Hasidy v vyshivankah $s$ sharovarami na granitse speli gimn Ukrainy".

25 "Fond Rabi Nachmana: Video s poiushchimi hasidami v kazatskih kostiumah - feik".

26 "Zaiavlenie OEOU po itogam prazdnovaniia Rosh Hashanah v Umani”; "Epidsytuacia w Umani pislia Rosh Hashanah"; "Serioznych porushen' ne bulo...”.

${ }_{27}$ Tsebrii, "Shanovni umanchany!...".
} 
should also be celebrating their holidays at home!" (by the Facebook user Lena Dzembak, 105 likes). Some of the commentators also admitted the political nature of this message, the unofficial start of an electoral campaign: "You understand that this is solved not on this level, why write nonsense? Pre-electoral PR is cheap. Everyone knows how much local government is earned on the Hasidim, and now it is probably finished... Money will solve everything, the opinions of the locals were never counted" (by the Facebook user Natalia Petrychenko, 14 likes, 2 comments).

In all the other posts, as well as in the interviews, Oleksandr Tsebrii articulated his position to ban the pilgrimage during the pandemic. He made a video of his appeal to the President of Ukraine Volodymyr Zelensky about this ban $^{28}$ and his night in a sleeping bag near the Administration of the President of Ukraine as a radical step to reach Volodymyr Zelensky. ${ }^{29}$ The mayor also supported the petition of Uman inhabitants to the President of Ukraine, ${ }^{30}$ which received 1,727 signatures (out of the 25,000 signatures necessary for a petition to be considered by the President). There could be several explanations as to why the petition did not become popular: a complicated procedure of registering a signature, a limited amount of people who wanted to support the petition, the limited circulation of information about the initiative, etc. The above-mentioned deputy Anton Iatsenko referred to the topic of the pilgrimage in Uman already in July (three appeals mentioned earlier) and articulated his position in favor of a total ban of the pilgrimage. What deserves attention is that Iatsenko ignored Tsebrii (both had a similar position on pilgrimage), but at the same time he supported the mayor of Cherkasy Anatolii Bondarenko by commenting and sharing the post of the former on Facebook. ${ }^{31}$ This demonstrates the existence of internal political tensions in Uman, in which the topic of opposing the pilgrimage played a mobilizing role for political rivals in attracting voters. After the elections, in November 2020, Anton Iatsenko became one of the authors of a parliamentary project aimed at developing Uman as an international Hasidic pilgrimage center. ${ }^{32}$

It is important to emphasize the general atmosphere of fear of the coronavirus from abroad, especially evident at the beginning of the pandemic (at that time - epidemic). In late February, a group of people who arrived in Ukraine from China was sent for a two-week observation in a settlement called Novi Sanzhary, Poltava region in Ukraine. They faced aggression, however, and the extreme unwillingness of the locals to live close to a possible source of infection. Both police and high-ranking officials had to be involved to resolve the situation..$^{33}$ As some pilgrims to Uman managed to arrive in Ukraine before the border closure, there were several incidents of a smaller scale, but of a similar nature, and they were sometimes called 'Novi Sanzhary-2' ${ }^{34}$ Sometime later, one of the local cafes, located

\footnotetext{
${ }^{28}$ Tsebrii, "Zvernennia do Prezydenta Ukrainy”.

29 "Mer Umani Oleksandr Tsebrii piketuie ofis Prezydenta".

${ }^{30}$ Chyrva, "Petytsia shchodo zaprovadzennia obmezhennia".

${ }^{31}$ Anton Iatsenko, "Boremos' razom! Repost: Anatoliy Bondarenko...”.

32 "Proekt Postanovy pro zvernennia Verkhovnoii Rady Ukrainy...”.

33 "Coronavirus: Ukraine protesters attack buses...".

34 "Novi Sanzhary-2, Czy vse pravyl'no robliat'?".
} 
close to the bus station of Uman, installed an outdoor announcement in a few languages, including Hebrew: "No entry to the Hasidim". ${ }^{35}$ This incident became a topic for media discussions on various levels. My informal observations of Uman-related Facebook and Viber groups demonstrated that many Uman locals supported the owner of the cafe. All this demonstrates the rather complicated socio-cultural context of the pilgrimage in 2020 .

The text level of discourse analysis shows the main characteristics of the texts analyzed, and the focal points for discussions about the Hasidic pilgrimage in 2020. In this regard, I took into account 39 materials (see Appendix 1).

Most of the materials on the topic belong to September (see Table 1), the actual period of pilgrimage - this fact can be interpreted as immediate official reactions to the ongoing events. The main actors, involved in communication about the pilgrimage, belong to the national level (24), local or regional level (12 messages), and even the international level (3 messages). I treated the materials representing the views of the Jewish community on the pilgrimage as national because they reflected either the opinion of the Chief Rabbi of Ukraine, or the United Jewish Community of Ukraine, or the Charity Foundation in Memory of Rabbi Nachman of Breslov directly involved in the pilgrimage. In general, such foci signify the importance of the topic far beyond local affairs in Uman.

After the end of the period of the expected pilgrimage (Rosh Hashanah on September 18-20, 2020 and the consequent Yom Kippur, or Atonement Day, on 27-28 September 2020), the attention of the officials to the topic faded. The only message taken into the analysis was the announcement of the deputy Anton Iatsenko (who became the deputy of the Parliament of Ukraine due to the votes in Uman) about his active participation in the local elections and specifically in the elections of the mayor (this occurred on October 25 and led to the victory of his candidate Iryna Pletniova in the position of new Uman mayor). Although this message did not touch on the topic of the Hasidim directly, it followed his previous posts about the ban of the pilgrimage and his care about Uman locals.

Table 1. Representation of the main agents of discourse by months

\begin{tabular}{|c|c|c|c|c|c|}
\hline Official body representation & July & August & September & October & Total \\
\hline Jewish community & & & 9 & & 9 \\
\hline Mayor (Oleksandr Tsebrii) & 1 & 5 & 2 & & 8 \\
\hline Government & 1 & 1 & 3 & & 5 \\
\hline National deputy (Anton Iatsenko) & 3 & 1 & & 1 & 5 \\
\hline Police & & & 3 & & 3 \\
\hline President of Ukraine & & 1 & 2 & & 3 \\
\hline Ambassador of Israel & & & 1 & & 1 \\
\hline President of Belarus & & & 1 & & 1 \\
\hline Regional authorities (Mayor of Cherkasy) & & & 1 & & 1 \\
\hline Local epidemiologist & & & 1 & & 1 \\
\hline Border control & & & 1 & & 1 \\
\hline American congressmen & & & 1 & & 1 \\
\hline Total & 5 & 8 & 25 & 1 & 39 \\
\hline
\end{tabular}

${ }^{35}$ Hazin, “Oleksandr Tsebrii, tse te, do chogo vy pragnuly?..”. 
The distribution of topics in the materials shows that the most popular topic was the total prohibition of the pilgrimage (see Table 2). This topic was discussed on the local level - first of all, by Anton Iatsenko, and secondly - by Oleksandr Tsebrii. The loudest systematic voice, however, belonged to the latter. Other messages were connected to the explanations of pilgrimage importance, regulations of the pilgrimage, and a question of allowance for the pilgrims to enter Ukraine (from outside voices and the voice of the Hasidic Charity foundation mentioned earlier). Messages about the misbehavior of pilgrims came from the press secretary of the National Police of Ukraine Anton Gerashchenko, which will be discussed later.

It deserves attention that reports about the pilgrimage were mostly made on the initiative of the pilgrims' side (including the commentary about the epidemiological situation on the "Uman media" channel connected to the Hasidim). It can be explained by the interest of the side to deliver information to the wider audience in a situation to create a more positive vision of the pilgrimage. Oleksandr Tsebrii, the main critic of the idea with Uman pilgrimage in 2020, also discussed the gift of $2.5 \mathrm{mln}$ Ukrainian hryvnias (which equals 44,600 euro) by Israeli patrons to the town's new diagnostic laboratory, ${ }^{36}$ which he counted as one of his victories in the fight for town's prosperity (with no articulated direct connection to the Hasidic pilgrimage). However, many of his commentators interpreted it as a payment for this year's pilgrimage.

I have differentiated between two competing discourses: "pilgrimage as a source of danger" and "pilgrimage as a proxy for Ukraine's good reputation". The first discourse could be

Table 2. The main topics in the materials analyzed

\begin{tabular}{|c|c|c|c|c|c|c|c|}
\hline & 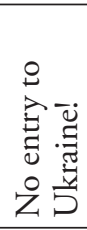 & 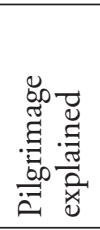 & 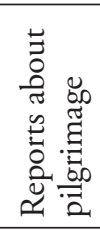 & 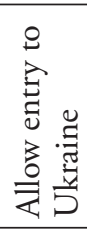 & 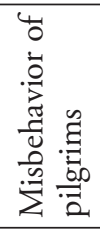 & 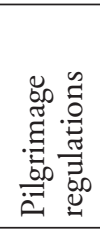 & $\frac{\dot{ \pm}}{5}$ \\
\hline Jewish community & & 5 & 3 & 1 & & & 1 \\
\hline Mayor (Oleksandr Tsebrii) & 7 & & & & & & 1 \\
\hline Government & 4 & & & & & 1 & \\
\hline National deputy (Anton Iatsenko) & 4 & & & & & & 1 \\
\hline Police & & & 1 & & 2 & & \\
\hline President of Ukraine & 1 & & & & & 1 & \\
\hline Ambassador of Israel & 1 & & & & & & \\
\hline President of Belarus & & & & 1 & & & \\
\hline Regional authorities (Mayor of Cherkasy) & 1 & & & & & & \\
\hline Local epidemiologist & & & 1 & & & & \\
\hline Border control & 1 & & & & & & \\
\hline American congressmen & & & & 1 & & & \\
\hline Total & 19 & 5 & 5 & 3 & 2 & 2 & 3 \\
\hline
\end{tabular}

36 Tsebrii, "Z pochatkom pandemii..." 
revealed by the reference to the pandemic, the guidelines of the World Health Organization or The Ministry of Health of Ukraine, the number of cases in the country, the reference to a country as 'green' (safe, from the perspective of contagion) or 'red' (unsafe, from the safe perspective), the numbers of potential pilgrims, and a pessimistic scenario for Uman locals after the pilgrimage. This discourse was reflected in the appeals of Oleksandr Tsebrii, Anton Iatsenko, Anatolii Bondarenko (representing the local level), for the documents of the Ministry of Foreign Affairs of Ukraine in July and mid-September, and the President of Ukraine Volodymyr Zelensky in September 2020.

This kind of discourse was supported by the comparison and contrasts with the Christian rituals and traditions restricted during springtime. These comparisons were visible in the official speech of the President of Ukraine ${ }^{37}$ and comments under the Facebook posts of Oleksandr Tsebrii. Some commentators saw restrictions for Christians in the spring as a form of punishment, not as care for health, and thus looked for the symbolic justice: "Our relatives in Heaven have understood us when we had our memorial day and we did not visit their graves. Nothing bad will happen to the Hasidim the same way", "We sat in our homes, it is their turn now".38

The discourse of danger received additional visual support with photos of disinfection, for instance from a local school No. 1, located near the pilgrimage district and reopened after the pilgrimage. The other examples belong to the visual messages of Anton Gerashchenko, speaker of the Ministry of Internal Affairs of Ukraine. Anton Gerashchenko wrote, for example, about the destruction of temporary constructions aimed at keeping social distance near the grave of Nachman by the Hasidim. He called these actions aggressive, stating: "Dear pilgrims, remember - you are the guests in Ukraine. Ukrainians are hospitable people, but we will not tolerate violence and rudeness on your side". ${ }^{39}$

Anton Gerashchenko also commented on the Belarusian-Ukrainian border stay of the Hasidim with photos demonstrating the abundance of garbage left after the pilgrims: "We warned the pilgrims that due to the pandemic we will not let them in regardless of their songs or dances. We asked the Belarusians not to let the pilgrims through their checkpoint. They did not listen. Now they will have to clean it up". ${ }^{40}$

His irony, however, speaks not only of the additional inconveniences caused by the pilgrims, but also emphasizes the inappropriateness of having pilgrims during the pandemic, the undesirable side effects of this pilgrimage, in general. I interpret it as an additional persuasive instrument to the discourse of danger.

The second discourse could be seen in the explanation of pilgrims' motivation to travel to Uman regardless of external factors, references to limitation and control of potential pilgrimages, obeying the laws of Ukraine, as well as appeals to the pilgrims not to come this year with an emphasis on the importance of Rosh Hashanah, in general. This discourse

\footnotetext{
37 "Prezydent zaklykav rabyniv Ukrainy dopomogty...".

${ }^{38}$ Tsebrii, "Shanovni umanchany!...".

${ }^{39}$ Gerashchenko, "Vchera v gorode Uman'...".

${ }^{40}$ Gerashchenko, "Palomniki-hasidy polnostiu osvobodili territoriiu.".
} 
was detected in the messages of representatives of the Jewish community and in the earlier messages of the Government of Ukraine and the President of Ukraine (August 2020). This discourse was formulated as negotiations of different sides (for instance, the President of Ukraine and the Prime Minister of Israel, the President of Ukraine, and the rabbis in Ukraine) and existed in the form of recommendations from the highest rank officials, not as a strict order or command. The examples are provided below:

"They (the Israeli government - A.M.) asked us to close down Uman. This holiday is very important. I am sure that our relationship will become stronger each year... But we are in a complicated situation" - explained Volodymyr Zelensky". ${ }^{41}$

"Following the recommendations and warnings of the Ministries of Health of Ukraine and Israel, we urge all pilgrims who plan to take part in this year's Rosh Hashanah celebrations in Ukraine to refrain from visiting the city of Uman due to the threatening epidemic situation. However, for those who decided to visit Uman, we would like to emphasize that quarantine restrictions in Ukraine apply to all public events and must be strictly adhered to". ${ }^{42}$ It is worthy of attention that the President of Ukraine Volodymyr Zelensky played a mediating role between the two discourses. In his Rosh Hashanah greeting, he combined restrictions with values and hope:

"For the sake of the life and health of people, the highest value, we were forced to restrict the mass events in the country, including the traditional celebration of this holiday. But in Kyiv, Dnipro, Uman, Jerusalem, New York and in other places on our planet the Jewish people pray for the peace and prosperity of the whole of mankind". ${ }^{43}$

The discourse of "pilgrimage as a proxy for Ukraine's good reputation" was also maintained in all the official reports after Rosh Hashanah - on the side of the police and the Jewish organizations. In these cases, the discourse was supported with such instruments: confirmation of the peaceful atmosphere during the pilgrimage, confirmation of following the medical guidelines by the pilgrims, confirmation of cooperation of all sides connected to the pilgrimage, the absence of bad epidemiological outcomes for the local population and thank-you words to the different organizations involved. In this vein, the reports could be interpreted as evidence of no danger, or as a counterargument to the first discourse.

Both discourses were supported by the same values articulated - the value of human life and the value of health. The instruments employed were different, however, while the first discourse was supported by the idea that the ban on the pilgrimage would save the life and health of Uman locals, while the second one contained messages about the obedience of the pilgrims to the rules and safety measures undertaken to maintain the above-mentioned values. The discussions around the pilgrimage during the pandemic could therefore be called the estimation of gain and loss from the pilgrimage in the frame of the above-mentioned values.

\footnotetext{
41 "Prezydent zaklykav rabyniv Ukrainy dopomogty...”.

42 "Spil'na ukrains'ko-izrail'ska uriadova zayava...".

43 Zelensky, "Shanovna ievreiska gromado Ukrainy...”.
} 
Given the uncertainty of the rapid development of the pandemic, it is not surprising that the first discourse connected with danger dominated the second one connected with reputation. It became especially clear at the end of August - in September when the borders of Ukraine were finally closed for the foreigners.

The documents analyzed unveiled the important problem of power and representation. Who represents the official authorities in Ukraine when it comes to the tentative question of the pilgrimage in Uman? The central power - the President of Ukraine and the Government of Ukraine, or the local power - mayors and deputies? As one might notice, their positions initially corresponded to two different discourses, and only in the period closer to pilgrimage were they uniform. As Oleksandr Tsebrii wrote ironically later, "it is good that Uman had an active mayor that managed to change the situation from above", while Anton Iatsenko wrote about his decisive role in the same story. The same question could be addressed to the side of the pilgrims: Who represents the pilgrims when it comes to the decisive questions? The Chief Rabbi of Ukraine, a certain community, a certain organization? Mikhael Tkach as the Head of the United Jewish Community of Ukraine claimed that "Moshe Reuven Azman, the Chief Rabbi of Ukraine, is not an authority for the pilgrims, because he represents a different Jewish stream". ${ }^{44}$ If so, who represented the pilgrims this year - the Jewish community, the Breslov Hasidic stream, some other streams? In a different message, Mikhael Tkach emphasized that "this year the celebration was extremely significant for the Jewish community of Ukraine". ${ }^{45}$

\section{Conclusions}

The case of the Hasidic pilgrimage to Uman during the pandemic, caused by the coronavirus Covid-19 in 2020, became a unique one due to its nature, the interpretation of the place from a historical perspective, the testament of Rabbi Nachman, and the specific rationality of the pilgrims aimed at overcoming any obstacles to reach their shrine.

This case revealed several problems connected with authority, representation and subordination. The local authorities of Uman, represented by the former mayor, manifested a strongly negative opinion about the pilgrimage during the pandemic. National authorities, represented by the President of Ukraine, were more ambiguous, demonstrating the political importance of the pilgrimage. The Ministry of Foreign Affairs and the Ministry of Health used different forms to demonstrate their position - from a strict ban to a milder recommendation and seeking compromises, and then again to certain clear restrictions. In their position about the full ban, national authorities referred to the Israeli government and interpreted their step as a reaction to the request from Israel.

The pilgrimage that took place was far smaller than in previous years $(2,000-2,500$ pilgrims), preceding the municipal elections in Ukraine, and became a hot topic in the

\footnotetext{
${ }^{44}$ Nikolaienko, "Hasydiv obduryly..".

45 Tkach, "Nasha komanda prisutstvovala v Umani".
} 
electoral campaign, most visible in the messages of the previous Uman mayor Oleksandr Tsebrii. These messages mirrored the discrepancy between the decision-making on the national and local level and the internal political rivalry. The unexpected closure of the Ukrainian borders for all foreigners for one month under the pretext of a fight with the pandemic could be interpreted as a means to prevent the mass pilgrimage to Uman and avoid international scandal. Both ambiguities of statements and the Jewish origin of Volodymyr Zelensky left the field open for positive expectations on the part of the pilgrims, some of whom managed to arrive in Ukraine before the borders were closed.

The two main and competing discourses distinguished in the analysis were "pilgrimage as a source of danger" and "pilgrimage as a proxy for Ukraine's good reputation". The first discourse was reflected in the appeals of the officials at the local level and mostly later the documents of the Ministry of Foreign Affairs of Ukraine and the President of Ukraine (September 2020). The second discourse was evident in the messages of representatives of the Jewish community and in the earlier messages of the Government units and the President of Ukraine (August 2020). The dominance of the discourse "pilgrimage as a source of danger" could be explained by the general atmosphere of panic in the mass media and fear of the foreigners during the pandemic, as well as by the suspicion of the locals that the pilgrims would not obey the quarantine measures.

At the same time, it does not seem surprising - on the contrary, the discourse about "pilgrimage as a checkpoint for Ukraine's good reputation" may be interpreted in this manner in the context of restrictive measures in other countries, and of a request from the Israeli government not to allow pilgrims in Ukraine. It could be explained, however, by the complicated fabric of the sociocultural context, when many important events both in Ukraine and outside Ukraine took place at the same time (protests in Belarus, municipal elections in Ukraine, intentions of politicians to show that Ukraine was strong enough to manage the pandemic, intentions of politicians to attract investments in Ukraine as a democratic state, etc.). Last but not least, there was the attempt of the Ukrainian topofficials (first of all, Volodymyr Zelensky) to fight the existing negative stereotypes about anti-Semitism in Ukraine with acceptance and positive declarations about the current Hasidic pilgrimages.

The case of the Hasidic pilgrimage in Uman in 2020 could serve as a unique model for building a common official position of various branches and levels of authority (from local to international) on a highly nuanced topic. Despite the above-mentioned discrepancies in official declarations, the pilgrimage was initially managed by common efforts, including those who asked pilgrims not to arrive in Ukraine (for instance, the United Jewish Community of Ukraine). The intentional focus on the official position of various sides connected to the pilgrimage left aside most non-official commentaries by the regular inhabitants of Uman in the social media, which can become a platform for further research. 


\section{Bibliography}

Zygmunt Bauman, "From Pilgrim to Tourist - or a Short History of Identity", in Gay du Hall (ed.) Questions of Cultural Identity. (London: Sage, 1996), 18-36.

David Biale et al. Hasidism: A New History. (Princeton University Press, Princeton and Oxford, 2018). 875 p.

"Catholic Church Cancels Guadalupe Pilgrimage over Pandemic," AP News. November 23, 2020. https:// apnews.com/article/pandemics-health-mexico-coronavirus-pandemic-mexico-city-80c8c6a22d93dd15a42f $6 \mathrm{ca} 8 \mathrm{fd} 33 \mathrm{a} 0 \mathrm{ab}$

“Coronavirus: Ukraine Protesters Attack Buses Carrying China Evacuees,” BBC News. February 21, 2020. https://www.bbc.com/news/world-europe-51581805

Norman Fairclough, "Critical Discourse Analysis as a Method in Social Scientific Research,” in Wodak, Ruth and Meyer, Michael (eds.), Methods of Critical Discourse Analysis. (London: Sage, 2001), 121-138.

"Hasidy v vyshivankah s sharovarami na granitse speli gimn Ukrainy," Glavred. September 17, 2020. https://glavred.info/ukraine/hasidy-v-vyshivankah-s-sharovarami-na-granice-speli-gimn-ukrainy-novostiukrainy-10204619.html.

Haim Hazin, "Oleksandr Tsebrii, tse te, do chogo vy pragnuly? Vy tse otrymaly". September 11, 2020. https://www.facebook.com/HAZINHAIM/posts/10158638546084836.

Daniele Hervieu-Leger, Religion as a Chain of Memory. (New Brunswick, New Jersey: Rutgers University Press, 2000).

Jomana Karadsheh and Tamara Qiblawi, “'Unprecedented' Hajj Begins - with 1,000 Pilgrims, rather than the usual 2 Million,” CNN news. July 29, 2020. https://edition.cnn.com/travel/article/hajj-2020-coronavirusintl/index.html.

Alla Marchenko, "Etic and Emic Approaches to the Collective Memory in Media Coverage of the Hasidic Pilgrimage to Uman," Discourse Context Media (2018), https://doi.org/10.1016/j.dcm.2018.06.003.

Alla Marchenko. "The Personal Is Political: Volodymyr Zelensky in the Spotlight of the International Mainstream Media," Baltic Worlds, Vol. VIII, 2-3 (2020): 100-112.

"Novi Sanzhary-2, Czy vse pravyl'no robliat'?," Bukvy. August 28, 2020. https://fb.watch/2G8gMcychY/.

Carlie Porterfield, “Lockdown' Is 2020's Word Of The Year, According To Collins Dictionary”, Forbes, November 10, 2020. https://www.forbes.com/sites/carlieporterfield/2020/11/10/ lockdown-is-2020s-word-of-the-year-according-to-collins-dictionary/.

"Proekt Postanovy pro zvernennia Verkhovnoii Rady Ukrainy do Kabinetu Ministriv Ukrainy, ministerstv, derzhavnyh sluzhb, agentstv, mistsevyh organi vlady shchodo zdiisnennia zahodiv, spriamovanyh narozvytok mista Uman iak mizhnarodnogo tsentru palomnytstva hasydiv" 4426. November 26, 2020. http://w1.c1. rada.gov.ua/pls/zweb2/webproc4_1?pf3511=70524.

Alasdair Sandford, "Coronavirus: Half of Humanity now on Lockdown as 90 Countries Call for Confinement," Euronews. April 3, 2020. https://www.euronews.com/2020/04/02/ coronavirus-in-europe-spain-s-death-toll-hits-10-000-after-record-950-new-deaths-in-24-hou.

Toi Staff, "No Lockdown, but Ministers Ban Bonfires, Close off Meron ahead of Lag B’Omer," The Times of Israel. 6 May 2020. https://www.timesofisrael.com/no-lockdown-but-ministers-banbonfires-close-off-meron-ahead-of-lag-bomer/. 
"Vid Korolivstva Troieshchyna do Koshernoii respubliky u seriali "Sluga narodu” pokazaly novu mapu Ukrainy," Glavkom. March 28, 2019. https://glavcom.ua/news/vid-korolivstva-trojeshchina-dokoshernoji-respubliki-u-seriali-sluga-narodu-pokazali-novu-mapu-ukrajini-580957.html.

Max Weber. Sociology of Religion (London: Methuen, 1971).

"Zaborona viizdu inozemtsiam - hto pidpadaie pid vykliuchennia...," Administratsia derzhavnoi prykordonnoi sluzhby Ukrainy. September 10, 2020. https://www.kmu.gov.ua/news/zaborona-vyizdu-inozemcyam-htopidpadaye-pid-viklyuchennya-ta-yaki-dokumenti-mozhut-pidtverditi-cil-poyizdki.

"Zelens'ky stvoryv komisiiu, iaka rozberet'sia iz korupstiieiu v Umani, shcho pereshkodzhaie zvedenniu synagogy," RISU. September 26, 2019. https://risu.ua/zelenskiy-stvoriv-komisiyu-yaka-rozberetsya-izkorupciyeyu-v-umani-shcho-pereshkodzhaye-zvedennyu-sinagogi_n100296.

\section{Appendix 1. List of materials included in the analysis}

Olga Chyrva, "Petytsia shchodo zaprovadzennia obmezhennia na provedennia masovyh religiynyh sviatkuvan' u m.Umani, u veresni 2020 roku, u zvyazku z epidemieiu COVID-19.” August 12, 2020. https:// petition.president.gov.ua/petition/103448

Stanislav Doshchitsyn, "Sytuatsia dynamichna": prykordonnyky rozpovily pro sproby hasydiv potrapyty do Ukrainy”, Ukraina24. September 16, 2020. https://ukraina24.segodnya.ua/ua/obshestvo-news/ 4403-situaciya-dinamicheskaya-pogranichniki-rasskazali-o-popytkah-hasidov-popast-v-ukrainu

“Epidsytuacia w Umani pislia Rosh Hashanah,” Uman media. September 29, 2020. https://www.youtube. com/watch?v=LBBikGdK1ig\&feature=emb_title

"Fond Rabi Nachmana: Video s poiushchimi hasidami v kazatskih kostiumah - feik," Jewish News. September 18, 2020. https://jewishnews.com.ua/society/fond-rabbi-naxmana-video-s-poyushhimixasidami-v-kazaczkix-kostyumax-fejk

Anton Gerashchenko, "Palomniki-hasidy polnostiu osvobodili territoriiu." September 18, 2020. https:// www.facebook.com/anton.gerashchenko.7

Anton Gerashchenko, "Vchera v gorode Uman'..." September 10, 2020. https://www.facebook.com/ 100002305693349/videos/3280517475368410/

Anton Iatsenko, "Boremos' razom! Repost: Anatoliy Bondarenko. Iak golova Cherkas'kogo regional'nogo viddilennia Asotsiatsii mist Ukrainy hochu zvernutysia do tsentral'noi vlady..." August 15, 2020. https:// www.facebook.com/permalink.php?story_fbid= $3223831081069151 \&$ \&d=100003268733364

Anton Iatsenko, "Nasha komanda idew Umans'ku mis'ku radu na mistsevyh vyborah..." October 8, 2020. https://www.facebook.com/watch/?v=370476300660390

Anton Iatsenko, “Tradytsiyno shchoroku na sviatkuvannia Rosh Hashanah do Umani pryiszdyt' bil'she 30 tysiach hasydiv." July 20, 2020. https://www.facebook.com/antonyatsenko200/?_cft_\%5b0\%5d= AZXg1xCa5Mu8sht_BsJGrOXCjnIzvIsLcrq14CdJHbLjfHXqWyV1FZKN_IaxC4gJRK97p6StTwkISKT FFcUtFTNELM9snKYYxhu64yo1ae1T-pOjcB8D8SPDTOkz4yEZe20plLzes9lluoErS48kA5lbE9MOcIl a7tdWggbhZmckiqH_f74hBAG_XiY9EHl-ZsEklIsUqypQEDaAapTBTv368_tn__=-UC\%2CP-R

Anton Iatsenko, "U ts'omu rotsi palomnyky-hasydy ne poiidut' do mista Umani sviatkuvaty Rosh Hashanah.” July 14, 2020. https://www.facebook.com/antonyatsenko200/posts/2569003680079203? xts_[0]=68.ARDco4m2saEpx0E7b5LJp4iFtjRlbTwr-kg-8hRZu6fGLAQ7mMsIOHNSsTPXBkK0qdLj bLu9vdpUO_JgpgFj3zs3eKZoi7q I2yvpvv2C CxYcBPU8Dzn0J9jhTeWFkUZZJw68UyyYZOx 7o1SN 
Jrw6Y64C Atz9aJbEfBYf9si_QQG GXItULwhD 4IDC1lap64UXeMKISHjSMtKkMRK9jYU6Rtrbx dRes1MJokFRMgHi9 RQ0dvx0ZQvo86oRSKuAE0RJUjbGYg9xZPENVHgQ0RjKoZ3HhFIdzJfL8EB rGVmgDhOobHTRoAQHtSH14G1stNd7cA19-MRiu0EdY25WPf9aFmjXxTrR

Anton Iatsenko, “U zviazku z pandemieiu ts'ogo roku Rosh Hashanah potribno provodyty v onlain-formati.” July 31, 2020. https:/www.facebook.com/antonyatsenko200/ posts/2583387991974105

“Kak bratslavskie hasidy Novii god v Umani otmechali - spetsreportazh OEOU.” September 21, 2020. https://jewishnews.com.ua/society/kak-braczlavskie-xasidyi-novyij-god-v-umani-otmechalispeczreportazh-oeou?fbclid=IwAR0vP8uXIjm_t3QVo6gS-wfmRBO4Lpob1emVeKjHyMzv5lr6M FEa5nkW0vI

Herb Keinon, “Zelensky to 'Post': Israel Requested Restrictions on Uman Pilgrims," Jerusalem Post. September 9, 2020. https://www.jpost.com/israel-news/ukrainian-president -to-post-israel-requested-restrictions-on-pilgrims-641676

“Komentar MZS Ukrainy shchodo sytuacii na ukrains'ko-bilorus'komu derzhavnomu kordoni," Ministerstvo zakordonnych sprav Ukrainy. September 15, 2020. https://mfa.gov.ua/news/ komentar-mzs-ukrayini-shchodo-situaciyi-na-ukrayinsko-biloruskomu-derzhavnomu-kordoni

"Komentar Ministerstva zakordonnyh sprav Ukrainy shchodo sytuacii na ukrains'ko-bilorus'komu derzhavnomu kordoni," Ministerstvo zakordonnych sprav Ukrainy. September 16, 2020. https://mfa.gov. ua/news/komentar-ministerstva-zakordonnih-sprav-ukrayini-shchodo-situaciyi-na-ukrayinskobiloruskomu-derzhavnomu-kordoni

“Komisia TEB i NS rozglianula pytannia sviatkuvannia Rosh Hashanah v Umani," Departament komunikacii Sekretariatu Kabinetu Ministriv Ukrainy. September 3, 2020. https://www.kmu.gov.ua/news/ komisiya-teb-i-ns-rozglyanula-pitannya-svyatkuvannya-rosh-ga-shana-v-umani

"Lukashenko poruchil pravitel'stvu dogovorit'sa s Ukrainoy o predostavlenii zelenogo koridora dlia palomnikov-hasidov," Belta. September 15, 2020.

https://www.belta.by/president/view/lukashenko-poruchil-pravitelstvu-dogovoritsja-s-ukrainojo-predostavlenii-zelenogo-koridora-dlja-406877-2020/

“Mer Umani Oleksandr Tsebrii piketuie ofis Prezydenta," Uman. August 18, 2020. https://umannews. city/read/misto/95750/mer-umani-oleksandr-cebrij-piketue-ofis-prezidenta

"Mizhnarodnii blagodiynii fond imeni Rabi Nachmana prosyt' dlia hasydiv robyty vyniatok," Procherk. September 15, 2020. https://procherk.info/news/7-cherkassy/85519-mizhnarodnij-blagodijnij-fondimeni-rabi-nahmana-prosit-dlja-hasidiv-robiti-vinjatok?fbclid=IwAR0NNm6qog6MfSCh35GAjS0W2S bdwHRkQXDKoUexpSD7nowQgivHx-9u33w

Natan Nissim Ben-Nun. "Na zhal', zmusheni konstatuvaty..." Uman Media. July 9, 2020. https://www. facebook.com/1542320689122412/photos/a.1565733833447764/3499785533375908/

Maria Nikolaienko, "Hasydiv obduryly - golova ievreiskoii gromady pro sytuatsiu na kordoni z Bilorussiu,” Ukraina24. September 15, 2020. https://ukraina24.segodnya.ua/ua/obshestvo-news /4376-hasidov-obmanuli-glava-evreyskoy-obshchiny-o-situacii-na-granice-s-belarusyu

Maria Nikolaienko, "U bagatioh tse meta zhyttia: golovnii rabyn Ukrainy rozpoviv, navishcho hasydy yizdiat' do Umani," Ukraina24. September 16, 2020. https://ukraina24.segodnya.ua/ua/ obshestvo-news/4408-u-mnogih-eto-cel-zhizni-glavnyy-ravvin-ukrainy-rasskazal-zachem-hasidy-ezdyat-vuman

"Ofitsiyne zvernennia MBF imeni Rabi Nachmana z Breslavu shchodo sviatkuvannia Rosh Hashanah w 2020 rotsi," 
Uman Media. September 23, 2020. https://uman-media.com.ua/news/item/779-ofitsiine-zvernenniambf-imeni-rabi-nakhmana-z-breslavu-shcho-do-sviatkuvannia-rosh-ha-shana-u-2020-rotsi. html?fbclid=IwAR0_8lz_GDXkWELpCiK5Gxerh8bYRshbnZORDLhiDo0pEGXbNA24J1yuSIg

"Posol Izrailu pro sytuaciiu z hasydamy: vony povynni povernutysia do Bilorusi, a zvidty - dodomu," Livii Bereg. September 17, 2020. https://lb.ua/society/2020/09/17/466156_posol_izrailyu_pro_ situatsiyu_z.html

"Prezydent zaklykav rabyniv Ukrainy dopomogty unyknuty masovogo skupchennia liudei pid czas sviatkuvannia Rosh Hashanah v Umani.” August 25, 2020. https://www.president.gov.ua/news/ prezident-zaklikav-rabiniv-ukrayini-dopomogti-uniknuti-masov-63013

"Prybuttia hasydiv w Uman tsiogo roku nemozhlyvo - Ministry of Foreign Affairs of Ukraine," $R B C$ Ukraina. July 14, 2020. https:/www.rbc.ua/ukr/news/pribytie-hasidov-uman-etom-godu-nevozmozhno-1594720013.html

«Serioznych porushen' ne bulo», - zastupnyk nachal'nyka GUNP v Cherkas'kii oblasti pro sviatkuvannia Rosh Hashanah," Umans'ka raiionna derzhavna administratsiia Cherkas'koii oblasti. September 23, 2020. https://uman-rda.gov.ua/news/1600956178/

Nataliia Sokyrchuk, "Mer Umani proty hasydiv: Derzhava povynna vziaty smilyvist' i povidomyty Izrail: iihaty ne treba!" Glavkom. August 18, 2020. https://glavcom.ua/interviews/mer-umani-proti-hasidivderzhava-povinna-vzyati-smilivist-povidomiti-izrajil-jihati-ne-treba-699821.html

"Spil'na ukrains'ko-izrail'ska uriadova zayava shchodo palomnytstva hasydiv do mista Umani z nagody sviatkuvannia Rosh Hashanah," Departament komunikacii Sekretariatu Kabinetu Ministriv Ukrainy. August 18, 2020. https://www.kmu.gov.ua/news/spilna-ukrayinsko-izrayilska-uryadova-zayava-shchodopalomnictva-hasidiv-do-m-uman-z-nagodi-svyatkuvannya-rosh-ga-shana

Mikhael Tkach, "Nasha komanda prisutstvovala v Umani." September 22, 2020 https://www.facebook. com/mikhail.tkatch/posts/4449248345148177

“Oleksandr Tsebrii: «Ia nikoly ne mriiav pro mers'ke krislo, ale komus' zhe treba bulo vziaty vidpovidal' nist' za misto u chasy kryzy," Sait partii "Propozytsiia”. August 6, 2020. https://proposition.org.ua/ oleksandr-czebrij-ya-nikoly-ne-mriyav-pro-merske-krislo-ale-komus-zhe-treba-bulo-vzyaty-vidpovidalnistza-misto-u-chasy-kryzy/?fbclid=IwAR0D3uNgKRnlvqGW6iWop7G5syG2iBTRpDydLIPdZjmbK3 UiDKajqx0ZkkU

Oleksandr Tsebrii, “Petytsia dostupna za posylanniam...” August 13, 2020. https://www.facebook.com/ Tsebriy.Oleksandr/posts/2702444750043177

Oleksandr Tsebrii, “Shanovni umanchany! Potribno poradytys'.” July 3. https://www.facebook.com/ watch/?v=821893821676193

Oleksandr Tsebrii, “Z pochatkom pandemii...” September 15, 2020. https:/www.facebook.com/ Oleksandr.Tsebriy/posts/1519142264936449

Oleksandr Tsebrii, “Zvernennia do Prezydenta Ukrainy.” August 7, 2020. https://www.facebook.com/ watch/?v=742363839946739

Tetiana Vorozhko, “Do dvoh tysiach hasydiv z USA prosyt' pustyty w Uman' grupa amerykan'skyh kongresmeniv," Golos Ameryky. September 11, 2020. https://ukrainian.voanews.com/a/uman-haredimusa/5569333.html

"V Umani u 6 hasydiv vyiavyly COVID-19, - mis'kii golova," Livii Bereg. September 4, 2020. https:// lb.ua/society/2020/09/04/465251_umani_shistoh_hasidiv_viyavili.html 
"Zaiavlenie OEOU po itogam prazdnovaniia Rosh Hashanah v Umani," Jewish News. September 21, 2020. https://jewishnews.com.ua/society/zayavlenie-oeou-po-itogam-prazdnika-rosh-a-shana-5781v-umani

Volodymyr Zelensky, “Shanovna ievreiska gromado Ukrainy...” September 18, 2020. https://www.facebook. com/zelenskiy95/posts/2635050086745351 